\title{
Role of an RNA polymerase interacting protein, MsRbpA, from Mycobacterium smegmatis in phenotypic tolerance to rifampicin
}

\author{
Correspondence \\ Dipankar Chatterji \\ dipankar@mbu.iisc.ernet.in
}

Received 11 August 2009

Revised 15 October 2009

Accepted 19 November 2009

\author{
Abhinav Dey, Amit Kumar Verma and Dipankar Chatterji \\ Molecular Biophysics Unit, Indian Institute of Science, Bangalore 560012, India
}

\begin{abstract}
Rifampicin and its derivatives are at the forefront of the current standard chemotherapeutic regimen for active tuberculosis; they act by inhibiting the transcription activity of prokaryotic RNA polymerase. Rifampicin is believed to interact with the $\beta$ subunit of RNA polymerase. However, it has been observed that protein-protein interactions with RNA polymerase core enzyme lead to its reduced susceptibility to rifampicin. This mechanism became more diversified with the discovery of RbpA, a novel RNA polymerase-binding protein, in Streptomyces coelicolor that could mitigate the effect of rifampicin on RNA polymerase activity. MsRbpA is a homologue of RbpA in Mycobacterium smegmatis. On deciphering the role of MsRbpA in M. smegmatis we found that it interacts with RNA polymerase and increases the rifampicin tolerance levels, both in vitro and in vivo. It interacts with the $\beta$ subunit of RNA polymerase. However, it was found to be incapable of rescuing rifampicin-resistant RNA polymerases in the presence of rifampicin at the respective $\mathrm{IC}_{50}$.
\end{abstract}

\section{INTRODUCTION}

Tuberculosis (TB) is responsible for the loss of more human lives every week than any other infectious disease. Chemotherapy for TB has resulted from the success of a handful of natural products and synthetic molecules that were tested as inhibitors for Mycobacterium tuberculosis. However, the chemotherapeutic options have been limited to a very small number of compounds, introduced $40-50$ years ago, viz. rifampicin, isoniazid, pyrazinamide and ethambutol, which form the armoury of the first-line chemotherapy against TB (Nguyen \& Thompson, 2006). Although a plethora of small-molecule inhibitors have been reported over the years targeting bacterial DNA-dependent RNA polymerase, the only drug approved for clinical administration for treating TB, along with other infectious diseases, is rifampicin. Rifampicin belongs to the family of ansamycins, which were discovered in a strain of Nocardia mediterranei (Villain-Guillot et al., 2007). Notwithstanding the efficacy of rifampicin in TB treatment, resistant mutants arise spontaneously, especially due to improper drug administration. Rifampicin resistance in all eubacterial species has been attributed to structural changes in RNA polymerase resulting from missense mutations in the $r p o B$ gene (Jin \& Gross, 1988; Miller et al., 1994). Apart from the classical mechanism of action of rifampicin on the $\beta$

Abbreviations: $\mathrm{AB}$, azidobenzoate; $\mathrm{NHS}, \mathrm{N}$-hydroxysuccinimide; sulfoHSAB, N-hydroxysulfosuccinimidyl-4-azidobenzoate; TB, tuberculosis.

Supplementary material is available with the online version of this paper. subunit, another mechanism has also been proposed (Artsimovitch et al., 2005). Rifampicin seems to be nearer to region 3 of the $\sigma$-factor than expected from the crystal structure of the rifampicin-core RNA polymerase complex. This proximity could provide an explanation for the $\sigma$ dependence of the inhibition of transcription by rifampicin; for example, the inhibition is stronger when the polymerase uses $\sigma^{70}$ compared with $\sigma^{32}$ (Węgrzyn et al., 1998).

M. tuberculosis exhibits rifampicin tolerance - a reversible physiological state involving lowered sensitivity to rifampicin - which limits bactericidal kinetics. In other words, rifampicin cannot quickly kill persistent populations of $M$. tuberculosis which are found in clinical disease. The long period of chemotherapy which is needed leads to poor patient compliance, and in turn, difficulties in disease control. Rifampicin-tolerant $M$. tuberculosis cells exhibit low but detectable levels of RNA polymerase activity in the presence of rifampicin (Hu et al., 2000). This behaviour was thought to be due to alternative forms of RNA polymerase holoenzymes associated with various factors, leading to lowered affinity of RNA polymerase to rifampicin. Rapid purification of RNA polymerase from biomass cultured to different stages of growth (Mukherjee \& Chatterji, 2008) showed that the $\mathrm{IC}_{50}$ of rifampicin for stationary-phase RNA polymerase was double that for exponential-phase RNA polymerase. The composition of the transcription complex at the stationary phase was studied; this revealed the association of several proteins 
with RNA polymerase throughout the purification process, prominent among them being GroEL1, DNA polymerase 1, transcription repair coupling factor and preprotein translocase. Thus, it was speculated that in the stationary phase, RNA polymerase could be insulated from rifampicin by such associated proteins. The role of a DNA replication machinery protein, DnaA, has recently been reported (Flåtten et al., 2009) with respect to its in vitro interaction with RNA polymerase in Escherichia coli, and the partial protection that RNA polymerase received from rifampicin as a result of this interaction.

In an independent line of study, a new protein, RbpA, was discovered in Streptomyces coelicolor (Newell et al., 2006). This protein can interact with RNA polymerase, causes rifampicin tolerance of RNA polymerase activity in vitro and leads to basal levels of rifampicin resistance in vivo. RbpA was earlier observed as a protein that copurifies with RNA polymerase preparations in S. coelicolor (Paget et al., 2001). This protein was named as RbpA (RNA polymerasebinding protein). Moreover, RbpA has sequence homologues exclusively in the actinomycete family, with nearest neighbours in mycobacteria. Paget et al. (2001) discovered $\mathrm{RbpA}$ as a part of the $\sigma^{\mathrm{R}}$ regulon in $S$. coelicolor. The comparison of the upstream sequence of $r b p A$ between $S$. coelicolor and $M$. tuberculosis revealed a strong conservation of the -10 and -35 regions, making $\sigma^{\mathrm{H}}$ a possible candidate for regulating $r b p A_{\text {Мтв }}$ (Rv2050). Interestingly, when $r b p A$ null mutants of $S$. coelicolor were transformed with the $M$. tuberculosis rbpA gene, the resistance to rifampicin increased from $0.75 \mu \mathrm{g} \mathrm{ml}^{-1}$ to $2 \mu \mathrm{g} \mathrm{ml}^{-1}$ in vivo, which pointed towards an analogous role of $r b p A_{M T B}$. Saturation mutagenesis studies carried out on M. tuberculosis have placed $r b p A_{M T B}$ (Rv2050) on the list of genes needed for optimal growth (Sassetti et al., 2003). The similarities and the speculations over mycobacterial RbpA made a compelling case for deciphering its role in mycobacteria, especially in the context of rifampicin tolerance. Bioinformatic analysis identified a homologue of $r b p A_{M T B}(\mathrm{Rv} 2050)$ in $M$. smegmatis in the form of the MSMEG_3858 product, which is $92 \%$ identical and $100 \%$ similar to $r b p A_{M T B}$. Here we report the role of
MSMEG_3858 (MsRbpA) with respect to rifampicin tolerance in mycobacteria. To the best of our knowledge, this is the first study on RbpA after that of Newell et al. (2006).

\section{METHODS}

Bacterial strains, plasmids and growth conditions. Mycobacterium smegmatis $\mathrm{mc}^{2} 155$ is the wild-type strain. SM07 is a recombinant strain derived from $\mathrm{mc}^{2} 155$, harbouring a chromosomal hexahistidine-encoding tag on the rpoC gene (Mukherjee \& Chatterji, 2008). $\mathrm{Jmc}^{2} 155$ and $\mathrm{JRmc}^{2} 155$ are plasmid-transformed versions of $\mathrm{mc}^{2} 155$, carrying the plasmids pJAM2 (Triccas et al., 1998) and pJAM2MsRbpA, respectively. SM0747, SM0734 and SM0748 are rifampicin-resistant variants of SM07. All M. smegmatis strains were grown on MB7H9 medium (Difco) (supplemented with Bacto-agar when required) along with $2 \%(\mathrm{w} / \mathrm{v})$ glucose and $0.05 \%(\mathrm{v} / \mathrm{v})$ Tween 80 (in the case of liquid cultures).

SM07, SM0747, SM0734 and SM0748 were grown with $50 \mu \mathrm{g}$ hygromycin $\mathrm{ml}^{-1}$. $\mathrm{Jmc}^{2} 155$ and $\mathrm{JRmc}^{2} 155$ were grown with $25 \mu \mathrm{g}$ $\mathrm{ml}^{-1}$ kanamycin. Rifampicin concentrations varied from $2.5 \mu \mathrm{g} \mathrm{ml}$ to $400 \mu \mathrm{g} \mathrm{ml}^{-1}$.

Escherichia coli strain $\mathrm{DH} 5 \alpha$ was used for cloning experiments. The protein expression and purification experiments were carried out using E. coli strain BL21(DE3) in Luria-Bertani medium.

All plasmids used in this study are listed in Table 1.

\section{Strain constructions}

$J_{m} \mathbf{2}^{2}$ 155. pJAM2 encodes an acetamide-inducible expression system used for the purification of recombinant proteins in M. smegmatis (Triccas et al., 1998). pJAM2 was electroporated into M. smegmatis $\mathrm{mc}^{2} 155$ competent cells and the transformants were selected on MB7H9 medium with $2 \%(w / v)$ glucose and kanamycin.

JRmc $^{2}$ 155. pJAM2MsRbpA contains MSMEG_3858 cloned in pJAM2. M. smegmatis $\mathrm{mc}^{2} 155$ competent cells were electroporated with pJAM2MsRbpA and the colonies were screened on MB7H9 medium supplemented with $2 \%(\mathrm{w} / \mathrm{v})$ glucose and kanamycin.

SM0747, SM0734 and SM0748. Construction of these strains is described in the Supplementary Methods available with the online version of this paper.

Table 1. Plasmids used in this study

\begin{tabular}{|lll|}
\hline Plasmid & \multicolumn{1}{c|}{ Description } & \multicolumn{1}{c|}{ Reference } \\
\hline pET21b & Cloning and expression vector & Novagen \\
pJAM2 & Shuttle vector for overexpression of genes in $M$. smegmatis & Triccas et al. (1998) \\
pETMsRbpA & MSMEG_3858 cloned in pET21b in NdeI-XhoI site & This work \\
pJAM2MsRbpA & MSMEG_3858 cloned in pJAM2 in BamHI-XbaI site & This work \\
pFPVH & Vector carrying $M$. tuberculosis $r$ rn promoter & Gift from Professor Jaya Tyagi, AIIMS \\
pVJP16 & Vector carrying $M$. tuberculosis rel promoter cloned in pSD5B & Jain et al. (2005) \\
pAZI0612A & M. tuberculosis RNA polymerase $\beta^{\prime}$ subunit cloned in pET3a & Gift from AstraZeneca, Bangalore \\
pAZI0611 & M. tuberculosis RNA polymerase $\beta$ subunit cloned in pET3a & Gift from AstraZeneca, Bangalore \\
pETRNAP $\alpha \mathrm{Ms}$ & M. smegmatis RNA polymerase $\alpha$ subunit cloned in pET21b & Kumar \& Chatterji (2008) \\
pETOsm & M. smegmatis RNA polymerase $\omega$ subunit cloned in pET21b & Mathew et al. (2005) \\
pARC8171 & M. tuberculosis SigA-overexpressing plasmid & Gift from AstraZeneca, Bangalore \\
\hline
\end{tabular}




\section{Plasmid constructions}

pETMsRbpA. MSMEG_3858 was amplified from M. smegmatis genomic DNA using PCR and primers MsRbpXNdF and MsRbpXNdR (see Table 2). The 367 bp amplicon was cloned in the XhoI/NdeI-digested pET21b vector (Novagen) to create pETMsRbpA. The clone was confirmed by DNA sequencing and MALDI-TOF MS from a sample obtained from in-gel trypsin digestion of the band corresponding to $14 \mathrm{kDa}$ in $15 \%$ SDS-PAGE.

pJAM2MsRbpA. Primers MsRbpJAM2f and MsRbpJAM2r (see Table 2) were used to amplify MSMEG_3858 from M. smegmatis genomic DNA, which was later cloned in pJAM2, pre-digested with XbaI/ BamHI. The clone was confirmed by PCR using internal primers pRbpintf and pRbpintr (see Table 2), specific for MSMEG_3858, as well as Western blotting using anti-MsRbpA antibody on acetamideinduced cultures.

Purification of His-tagged MsRbpA. pETMsRbpA was transformed into E. coli BL21(DE3) and after $3 \mathrm{~h}$ of induction with $1 \mathrm{mM}$ IPTG, cells were harvested. The pellet was resuspended in $20 \mathrm{ml}$ icecold lysis buffer [50 mM Tris/HCl, $5 \%(\mathrm{v} / \mathrm{v})$ glycerol, $0.1 \mathrm{mM}$ EDTA, $1 \mathrm{M} \mathrm{NaCl}, 1 \mathrm{mM}$ DTT, $6 \mathrm{mM} \beta$-mercaptoethanol, $1 \mathrm{mM}$ imidazole, $23 \mu \mathrm{g}$ PMSF ml ${ }^{-1}, 200 \mu \mathrm{g}$ hen egg white lysozyme $\mathrm{ml}^{-1}, \mathrm{pH}$ 7.8]. The remaining steps of the protocol were similar to the method followed by Kumar \& Chatterji (2008).

Pull-down assay for wild-type lysate of $\boldsymbol{M}$. smegmatis over an

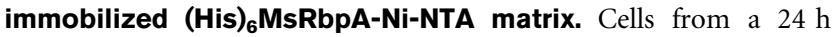
culture of $M$. smegmatis $\mathrm{mc}^{2} 155$ were resuspended in lysis buffer [50 mM Tris/HCl, 5\% (v/v) glycerol, $0.1 \mathrm{mM} \mathrm{EDTA,} 1 \mathrm{M} \mathrm{NaCl}$,
$1 \mathrm{mM}$ DTT, $6 \mathrm{mM} \beta$-mercaptoethanol, $23 \mu \mathrm{g}$ PMSF ml ${ }^{-1}, 200 \mu \mathrm{g}$ hen egg white lysozyme $\mathrm{ml}^{-1}, \mathrm{pH}$ 7.8] and incubated in ice for $30 \mathrm{~min}$ with $0.2 \%(\mathrm{w} / \mathrm{v})$ sodium deoxycholate, with occasional shaking. After incubation, the suspension was subjected to sonication and French press treatment. The lysate was centrifuged and the supernatant was treated with $0.6 \%(\mathrm{v} / \mathrm{v})$ polyethylenimine $\mathrm{P}$ and centrifuged. The resulting pellet was extracted with $1 \mathrm{M} \mathrm{NaCl}$ in TGEB buffer [10 mM Tris/HCl, $5 \%$ (v/v) glycerol, $0.1 \mathrm{mM}$ EDTA, $6 \mathrm{mM} \beta$-mercaptoethanol] followed by $50 \%$ ammonium sulfate precipitation. The pellet was resuspended in TGEB containing $1 \mathrm{M}$ $\mathrm{NaCl}$ and $1 \mathrm{mM}$ imidazole and kept for binding with a Ni-NTA matrix, pre-equilibrated with purified (His) ${ }_{6} \mathrm{MsRbpA}$. After $6 \mathrm{~h}$ incubation on a rotary shaker at $4{ }^{\circ} \mathrm{C}$, the Ni-NTA matrix was washed with 100 column volumes of TGEB buffer containing $0.6 \mathrm{M} \mathrm{NaCl}$ and $10 \mathrm{mM}$ imidazole. (His) ${ }_{6} \mathrm{MsRbpA}$ and associated proteins were eluted in TGEB buffer with $400 \mathrm{mM} \mathrm{NaCl}$ and $250 \mathrm{mM}$ imidazole.

Reconstitution of a heterologous mycobacterial core RNA polymerase. The various subunits of core RNA polymerase were purified as described in the Supplementary Methods. The reconstitution was carried out by dialysing $2 \mathrm{mg}$ purified $M$. smegmatis RNA polymerase $\alpha$ subunit ( $50 \mathrm{nmol}$ ), $8 \mathrm{mg}$ each of purified M. tuberculosis RNA polymerase $\beta^{\prime}$ subunit and $M$. tuberculosis RNA polymerase $\beta$ subunit (100 nmol each), and $M$. smegmatis RNA polymerase $\omega$ subunit $(50 \mathrm{nmol})$, against storage buffer $[100 \mathrm{mM}$ Tris/HCl $\mathrm{pH} 7.9$, $50 \%(\mathrm{v} / \mathrm{v})$ glycerol, $0.1 \mathrm{mM}$ EDTA, $0.15 \mathrm{M} \mathrm{KCl}$ and $0.1 \mathrm{mM} \mathrm{DTT]}$ overnight. The overall concentration of all the proteins was kept below $0.5 \mathrm{mg} \mathrm{ml}^{-1}$. This fraction was subsequently mixed with $\mathrm{Ni}$ NTA agarose (equilibrated in storage buffer) and kept for binding at $4{ }^{\circ} \mathrm{C}$ for $6 \mathrm{~h}$. The column was then washed with five column volumes of TGEB buffer [50 mM Tris/ $\mathrm{HCl} \mathrm{pH} 7.9,5 \%(\mathrm{v} / \mathrm{v})$ glycerol, $6 \mathrm{mM}$

Table 2. Primers used in this study

\begin{tabular}{|c|c|c|c|}
\hline Primer & Sequence $\left(5^{\prime}-3^{\prime}\right)$ & Purpose & Vector \\
\hline MsRbpXNdR & GTCAGCTCGAGTGTGCTTCCGG & Reverse primer for cloning of MSMEG_3858 & $\mathrm{pET} 21 \mathrm{~b}$ \\
\hline MsRbpJAM2r & CCTCAGCTCTCTAGAGCTTCCGGT & Reverse primer for cloning of MSMEG_3858 & pJAM2 \\
\hline pRbpintf & TCGGAGCCGTGAGCTACGAGAC & $\begin{array}{l}\text { Internal forward primer to screen for cloned } \\
\text { MSMEG_3858 inside plasmids }\end{array}$ & $\begin{array}{l}\text { pETMsRbpA and } \\
\text { pJAM2MsRbpA }\end{array}$ \\
\hline PrelF & GTGTCGTGATCATTGACGACG & $\begin{array}{l}\text { Forward primer for amplification of } \\
\text { M. tuberculosis rel promoter for in vitro } \\
\text { transcription assays }\end{array}$ & pVJP16 \\
\hline PrelR & CTGGTCTTAAGAGTCTCGACCG & $\begin{array}{l}\text { Reverse primer for amplification of } \\
\text { M. tuberculosis rel promoter for in vitro } \\
\text { transcription assays }\end{array}$ & pVJP16 \\
\hline RNCR & ACCTTGACGCTGTGCAGCGTCTTC & $\begin{array}{l}\text { Reverse primer to screen for mutations in } \\
\text { N-terminal } \text { Rif }^{\mathrm{R}} \text { cluster of } M \text {. smegmatis } \\
\text { rpoB gene }\end{array}$ & \\
\hline R3CF & CGTCGGTGAGCTGATCCAGAACCAGATCC & $\begin{array}{l}\text { Forward primer to screen for mutations in } \\
\text { Rif }^{\mathrm{R}} \text { clusters I, II and III of M. smegmatis } \\
r p o B \text { gene }\end{array}$ & \\
\hline R3CR & CCATGACCGTGATGTAGTCGGCCGAGA3 & $\begin{array}{l}\text { Reverse primer to screen for mutations in } \\
\text { Rif }^{\mathrm{R}} \text { clusters I, II and III of M. smegmatis } \\
\text { rpoB gene }\end{array}$ & \\
\hline
\end{tabular}


$\beta$-mercaptoethanol, $0.1 \mathrm{mM}$ EDTA]. The bound proteins were eluted with TGEB $+0.4 \mathrm{M} \mathrm{NaCl}+250 \mathrm{mM}$ imidazole. The eluted fractions were dialysed against TGED $+0.4 \mathrm{M} \mathrm{NaCl}$ for $12 \mathrm{~h}$ in two batches to remove imidazole. This fraction was subjected to another dialysis in TGED + 0.15 M NaCl. The final dialysed fraction was loaded onto a heparin-Sepharose column (prequilibrated with TGED $+0.15 \mathrm{M}$ $\mathrm{NaCl}$ ) and kept for binding for $6 \mathrm{~h}$. The column was washed with five column volumes of TGED $+0.15 \mathrm{M} \mathrm{NaCl}$ buffer. The proteins were eluted with TGED $+0.6 \mathrm{M} \mathrm{NaCl}$ buffer. The eluted fractions were then analysed for their purity by $10 \%$ SDS-PAGE and subsequently assayed for RNA synthesis activity.

Promoter-specific single-round gel-based transcription assay. The M. tuberculosis rel promoter was amplified from pVJP16 (Jain et al., 2005) using primers PrelF and PrelR (Table 2). The amplicon thus obtained was used as a template for the single-round promoter-specific transcription assay. Purified $\sigma^{\mathrm{A}}(200 \mathrm{nM})$ from M. tuberculosis was incubated with reconstituted core RNA polymerase $(100 \mathrm{nM})$ in molar ratio $2: 1$ in transcription buffer $\left[40 \mathrm{mM}\right.$ Tris/ $\mathrm{HCl}, 10 \mathrm{mM} \mathrm{MgCl}_{2}$, $75 \mathrm{mM} \mathrm{KCl}, 0.1 \mathrm{mM}$ EDTA, $0.1 \mathrm{mM}$ DTT, $14 \mathrm{mM} \beta$-mercaptothanol, $0.025 \mathrm{mg} \mathrm{ml}^{-1} \mathrm{BSA}$ (nuclease free)] at $37{ }^{\circ} \mathrm{C}$ for $10 \mathrm{~min}$. The DNA template rel amplicon $(10 \mathrm{nM})$ was then added at a 0.1 molar ratio to RNA polymerase and a further incubation of $37{ }^{\circ} \mathrm{C}$ for $5 \mathrm{~min}$ was carried out. Finally, the NTP mix comprising $0.15 \mathrm{mM}$ ATP, $0.15 \mathrm{mM}$ GTP, $0.15 \mathrm{mM}$ CTP, $0.05 \mathrm{mM}$ UTP, $2 \mu \mathrm{Ci}(74 \mathrm{kBq})\left[{ }^{32} \mathrm{P}\right] \mathrm{UTP}$ and $200 \mu \mathrm{g}$ heparin $\mathrm{ml}^{-1}$ was added, followed by incubation for $30 \mathrm{~min}$ at $37^{\circ} \mathrm{C}$. The reaction was stopped by addition of stop solution (5 mM EDTA and $100 \mu \mathrm{g}$ E. coli tRNA ml ${ }^{-1}$ ). The transcription products were subjected to $10 \%$ denaturing PAGE in the presence of $6 \mathrm{M}$ urea and analysed by phosphorimager (FLA2000; Fujifilm) (Chowdhury et al., 2007).

In the transcription reactions involving the addition of rifampicin, the core RNA polymerase, $\sigma^{\mathrm{A}}$ and rifampicin were incubated together in transcription assay buffer at $37^{\circ} \mathrm{C}$ for $10 \mathrm{~min}$ before the addition of DNA, NTPs and heparin. In the transcription reactions involving the presence of MsRbpA, the core RNA polymerase, $\sigma^{\mathrm{A}}$ and rifampicin were incubated together in transcription assay buffer at $37^{\circ} \mathrm{C}$ for $10 \mathrm{~min}$ and then MsRbpA was added to the mix followed by incubation at $37{ }^{\circ} \mathrm{C}$ for $5 \mathrm{~min}$. This was followed by addition of DNA, NTP and heparin in order to complete the transcription reaction.

Cross-linking of MsRbpA with RNA polymerase using the heterobifunctional cross-linker sulfo-HSAB. With the objective of determining the binding partner of MsRbpA on RNA polymerase, a chemical cross-linking reaction was carried out between MsRbpA and M. smegmatis RNA polymerase. Sulfo-HSAB ( $N$-hydroxysulfosuccinimidyl-4-azidobenzoate; Pierce) was used as a cross-linker. M. smegmatis core RNA polymerase was purified from a $30 \mathrm{~h}$ culture and dialysed in PBS (pH 7.8). (His) ${ }_{6} \mathrm{MsRbpA}$ labelled with $\left[{ }^{35} \mathrm{~S}\right]$ methionine was also purified and dialysed against PBS (pH 7.8). ${ }^{35}$ S-labelled (His) ${ }_{6} \mathrm{MsRbpA}$ $(70 \mu \mathrm{M})$ was mixed with 50 -fold molar excess of sulfo-HSAB dissolved in PBS (pH 7.8). After incubation at $37{ }^{\circ} \mathrm{C}$ in the dark for $30 \mathrm{~min}$, the mix was loaded on a Sephadex-G25 column to separate unreacted sulfoHSAB from the protein. The labelling of MsRbpA with sulfo-HSAB was followed by monitoring the increase in $A_{260}$ as a measure of $\mathrm{N}$ hydroxysuccinimide (NHS) ester hydrolysis caused as a result of labelling. The protein was detected in the void volume by scintillation counting. The labelled MsRbpA was incubated with fivefold molar excess of RNA polymerase at $37^{\circ} \mathrm{C}$ for $30 \mathrm{~min}$ followed by exposure to $254 \mathrm{~nm}$ UV light for $8 \mathrm{~min}$. The reaction mix was immediately subjected to $12 \%$ SDS-PAGE, and the complexes formed as a result of chemical cross-linking were detected with anti-MsRbpA antibodies, and antibodies against the $M$. tuberculosis $\beta^{\prime}$, M. tuberculosis $\beta$, M. smegmatis $\alpha$ and $M$. smegmatis $\omega$ subunits of RNA polymerase (subsequently referred to as anti-M. tuberculosis $\beta^{\prime}$, anti-M. tuberculosis $\beta$, anti- $M$. smegmatis $\alpha$ and anti-M. smegmatis $\omega$ antibodies).

\section{RESULTS}

\section{MsRbpA is highly conserved in pathogenic and non-pathogenic mycobacterial species}

RbpA was discovered as a protein co-eluting with RNA polymerase during purification from S. coelicolor (Paget et al., 2001). The characterization of this protein for its role in rifampicin resistance in $S$. coelicolor was reported later by the same group (Newell et al., 2006). Bioinformatic analysis identified an RbpA homologue in M. smegmatis with accession number MSMEG_3858, which was $92 \%$ identical to the M. tuberculosis relative Rv2050 (Fig. 1). Further analysis revealed that MsRbpA homologues are highly conserved in mycobacterial species (Fig. 2). Another conspicuous feature is the occurrence of a homologue of RbpA in Nocardia farcinica (Supplementary Fig. S1), the only sequenced genome from the genus Nocardia, which includes the rifampicin producer, $N$. rifamycinica. This could be a possible defence mechanism that Nocardia might use against its own metabolite rifampicin.

\section{MsRbpA can interact with RNA polymerase}

MsRbpA was tagged with a stretch of six histidines at the C-terminus by cloning MSMEG_3858 in pET21b (pre-
S.coelicolor A3(2) SCO1421 M.tuberculosis H37Rv Rv2050 M. smegmatis $\mathrm{mc}^{2} 155$ MSMEG 3858

S.coelicolor A3(2) SC01421 M.tuberculosis H37Rv Rv2050 M. smegmatis $\mathrm{mc}^{2} 155$ MSMEG3858
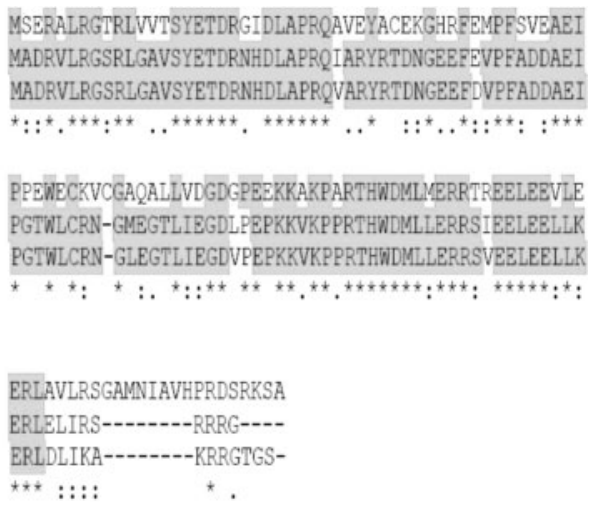

Fig. 1. Bioinformatic search for homologues of $S$. coelicolor RbpA (SCO1421) and $M$. tuberculosis RbpA (Rv2050) in the genome of M. smegmatis $\mathrm{mc}^{2} 155$. The BLAST search revealed the existence of a homologue MSMEG_3858 showing 50\% amino acid sequence identity with SCO1421 and 92\% identity with Rv2050. 
MT_2110_M.tuberculosis CDC155

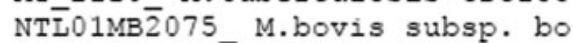
NTL02MT02045 M.tuberculosis H NTL03MA1798_M. avium paratuber MAV 2447 M.avium 104 NTL $\overline{0} 1 \mathrm{ML} 1 \overline{4} 40$ M. leprae TN MSMEG 3858

MSMEG_3858_ M.smegmatis MC2

MT_2110 M.tuberculosis CDC155

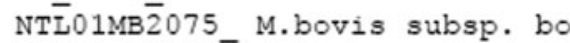
NTL02MT02045 M.tuberculosis H NTL03MA1798_M.avium paratuber MAV_2447_M.avium 104

NTL $\overline{0} 1 \mathrm{ML} 1 \overline{4} 40$ M. leprae TN

MSMEG_3858

MSMEG_3858_M.smegmatis MC2

MT_2110_M.tuberculosis CDC155 NTĒ01MB $\overline{2} 075$ M.bovis subsp. bo NTL02MT02045 M.tuberculosis H NTL03MA1798_M.avium paratuber MAV 2447 M. avium 104 NTL $\overline{0} 1 \mathrm{ML} 1 \overline{4} 40$ M. leprae TN MSMEG_3858

MSMEG_3858_M.smegmatis MC2
MADRVLRGSRLGAVSYETDRNHDLAPRQIARYRTDNGEEFEVPFADDAEI MADRVLRGSRLGAVSYETDRNHDLAPRQIARYRTDNGEEFEVPFADDAEI MADRVLRGSRLGAVSYETDRNHDLAPRQIARYRTDNGEEFEVPFADDAEI MADRVLRGSRLGAVSYETDRNHDLAPRQIARYRTENGEEFEVPFADDAEI $-------M S Y E T D R N H D L A P R Q I A R Y R T E N G E E F E V P F A D D A E I$ MADRVLRGSRLGAVSYETDRNHDLAPRQIARYRTDNGEEFEVPFADDADI MADRVLRGSRLGAVSYETDRNHDLAPRQVARYRTDNGEEFDVPFADDAEI MADRVLRGSRLGAVSYETDRNHDLAPRQVARYRTDNGEEFDVPFADDAEI

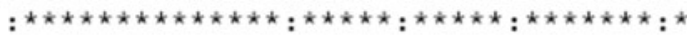

PGTWLCRNGMEGTLIEGDLPEPRKVRP PRTHWDMLIERRS IEELEELIKE PGTWLCRNGMEGTLIEGDLPEPRKVKPPRTHWDMLLERRS IEELEELLRE PGTWLCRNGMEGTLIEGDLPEPRKVKPPRTHWDMLLERRS IEELEELLKE PGTWLCRNGMEGTLIEGDLPEPRKVKPPRTHWDMLIERRS IEELEELLKE PGTWLCRNGMEGTLIEGDLPEPKKVKPPRTHWDMLLERRS IEELEELLKE PGTWLCRNGMEGTLIEGDLPEPRMVKPPRTHWDMLLERRS IEELEELLKE PGTWLCRNGLEGTLIEGDVPEPRKVKPPRTHWDMLLERRSVEELEELLKE PGTWLCRNGLEGTLIEGDVPEPRKVKPPRTHWDMLLERRSVEELEELLKE

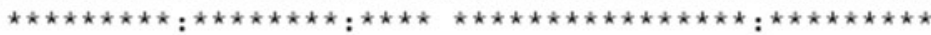

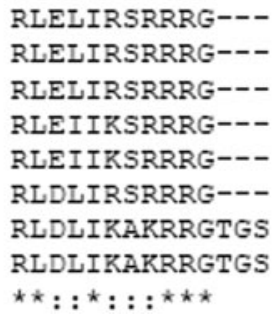

Fig. 2. Multiple sequence alignment of MSMEG_3858 with other mycobacterial homologues in pathogenic mycobacterial species using CLUSTAL W 2.

digested with NdeI and $\mathrm{XhoI}$ ). The protein purified as MsRbpA was confirmed by DNA sequencing and MALDITOF MS (Supplementary Fig. S2, Supplementary Table S1). The (His) ${ }_{6} \mathrm{MsRbpA}$ was immobilized on a Ni-NTA matrix (Qiagen); wild-type M. smegmatis lysate fractionated with $50 \%$ ammonium sulfate was loaded on the matrix, and left for binding overnight at $4{ }^{\circ} \mathrm{C}$. The eluates obtained showed the presence of RNA polymerase (Fig. $3 a)$. The eluates were screened for RNA polymerase subunits using anti-M. tuberculosis $\beta^{\prime}$ and anti-M. tuberculosis $\beta$ antibody (Fig. 3b). However, a pull-down assay on crude cell lysate is not the best way to establish protein-protein interaction (Mackay et al., 2007). Therefore, we repeated the pull-down assay using a pure RNA polymerase from wild-type M. smegmatis (Fig. 3c, Supplementary Fig. S3). The pull-down assay using purified RNA polymerase reconfirmed the interaction between MsRbpA and RNA polymerase and also indicated that this interaction was not mediated by other proteins present in the cell lysate.

\section{MsRbpA rescues RNA polymerase from the inhibitory effect of rifampicin}

In order to test the role of MsRbpA in rescuing RNA polymerase from the inhibitory effect of rifampicin, we reconstituted core RNA polymerase comprising pure $\beta^{\prime}, \beta$, $\alpha$ and $\omega$ subunits from either $M$. tuberculosis or $M$. smegmatis (Supplementary Fig. S4). Due to the greater than $90 \%$ identity in different subunits of RNA polymerase across the species of mycobacteria, the reconstituted enzyme is the same from either of the species. The purpose of reconstitution was to rule out any possibility of other proteins which might co-purify with RNA polymerase and influence the results. We tested those concentrations of rifampicin where the transcription activity is completely inhibited and challenged the same conditions with the addition of MsRbpA (Fig. 4a). We found that MsRbpA could rescue the in vitro activity of RNA polymerase in a promoter-specific single-round transcription assay, carried out from the rel promoter of M. tuberculosis (Jain et al., 2005). Transcription occurred even at $100 \mu \mathrm{M}$ rifampicin, when the molar ratio of RNA polymerase to MsRbpA was kept at $1: 2$. When we increased the molar ratio of RNA polymerase to MsRbpA from $1: 0.5$ to $1: 3$ at constant rifampicin concentration of $40 \mu \mathrm{M}$ (Fig. $4 \mathrm{~b}$ ), we observed that the use of threefold molar excess of MsRbpA restored the in vitro activity of RNA polymerase to the normal level.

\section{Overexpression of MsRbpA in M. smegmatis increases rifampicin tolerance}

We cloned MsRbpA under the acetamidase promoter in pJAM2 (Triccas et al., 1998) and electroporated the 


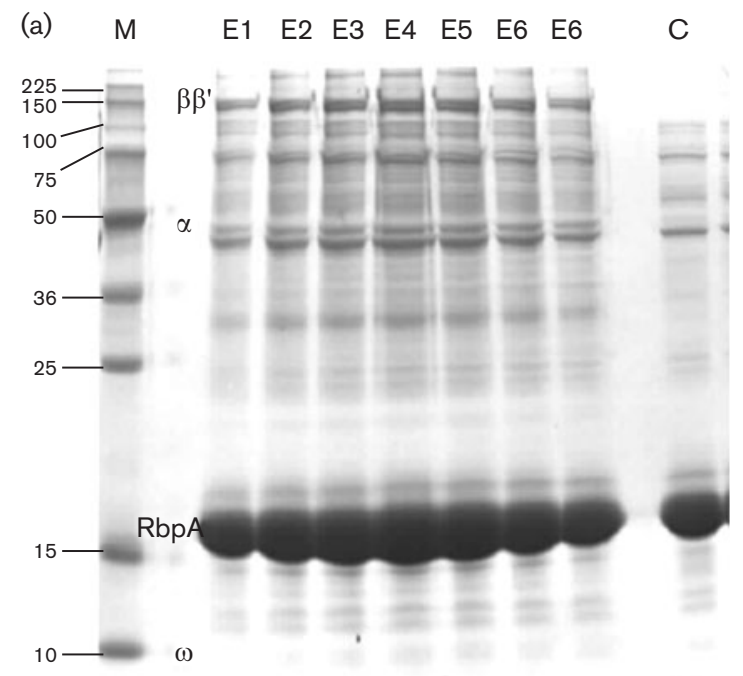

(b)

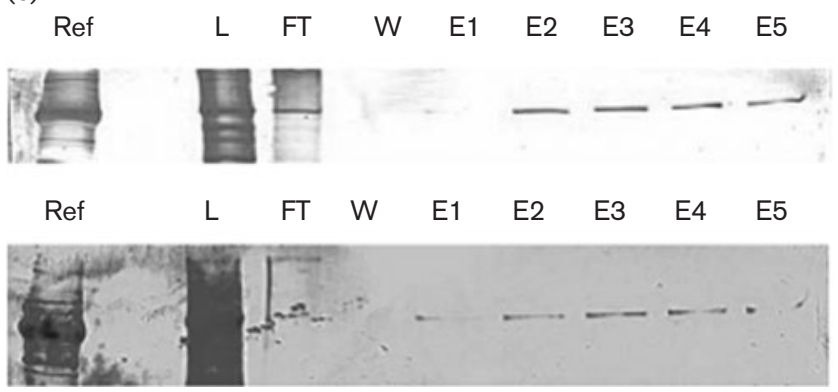

(c)

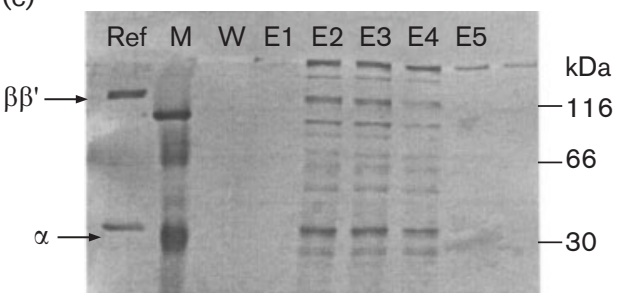

construct pJAM2MsRbpA into competent $\mathrm{mc}^{2} 155$ cells. As a control, pJAM2 vector was also electroporated into competent $\mathrm{mc}^{2} 155$ cells. The vector pJAM2 has a kanamycin-resistance marker. The resulting strains $\mathrm{Jmc}^{2} 155$ (carrying pJAM2) and $\mathrm{JRmc}^{2} 155$ (carrying pJAM2MsRbpA) were tested at different concentrations of rifampicin. The strain overexpressing MsRbpA in the inducing conditions of $2 \%$ acetamide grew at rifampicin concentrations of 20,40 and $80 \mu \mathrm{g} \mathrm{ml}^{-1}$, while the strain carrying pJAM2 was incapable of growing at these concentrations (Fig. 5a). The MIC of rifampicin for $\mathrm{Jmc}^{2} 155$ was $20 \mu \mathrm{g} \mathrm{ml}^{-1}$ while that

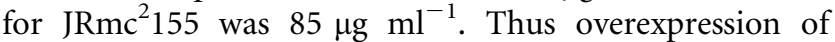
MsRbpA leads to an increase in the rifampicin tolerance levels in an otherwise rifampicin-sensitive strain. Colony morphology was compared between wild-type $M$. smegmatis transformed with pJAM2 (Jmc $\left.{ }^{2} 155\right)$ and pJAM2MsRbpA (JRmc $\left.{ }^{2} 155\right)$. The MsRbpA-overexpressing strain showed smaller colonies compared to the vector-carrying strain (Fig.
Fig. 3. Interaction between $M s R b p A$ and $M$. smegmatis RNA polymerase. (a) (His) ${ }_{6} \mathrm{MsRbpA}$ was immobilized over a Ni-NTA agarose column. $M$. smegmatis wild-type culture was grown and cells were lysed as described in Methods. The supernatant of the lysate after $50 \%$ ammonium sulfate precipitation was treated with the affinity matrix and subsequently eluted with $250 \mathrm{mM}$ imidazole. Lane $\mathrm{M}$ contains molecular mass markers (Perfect Protein Marker, Novagen); lane $\mathrm{C}$, the elution of (His) 6 MsRbpA without any treatment with lysate, served as control. Lanes E1 to E6 show different elution fractions, all containing RNA polymerase subunits, as proved by Western analysis. (b) Western analysis for RNA polymerase subunits $\beta^{\prime}$ (upper panel) and $\beta$ (lower panel), using polyclonal antibodies developed against $M$. tuberculosis $\beta^{\prime}$ and $\beta$ subunits, for detection of RNA polymerase co-eluting in the NiNTA agarose pull-down assay carried out using immobilized (His) ${ }_{6}$ MsRbpA. Ref, RNA polymerase; L, load of processed cellfree lysate; FT, flowthrough; W, wash; E1 to E5, elutions 1 to 5. (c) Ni-NTA agarose pull-down assay carried out using immobilized (His) ${ }_{6} \mathrm{MsRbpA}$ on purified RNA polymerase from wild-type $M$. smegmatis. A $10 \mu \mathrm{mol}$ sample of RNA polymerase was mixed with $70 \mu \mathrm{mol}$ (His) ${ }_{6} \mathrm{MsRbpA}$ and loaded on an Ni-NTA agarose column; elutions were carried out at $250 \mathrm{mM}$ imidazole. (Ref, reference core RNA polymerase; $M$, markers; W, wash; E1 to E5, elutions 1 to 5 ).

5b). We also carried out growth-dependent Western blot analysis using anti-MsRbpA antibody on wild-type $M$. smegmatis lysates to determine the levels of MsRbpA (Fig. 5c). The level of MsRbpA increased in stationary-phase cultures of $M$. smegmatis. However, the level of expression was much less as compared to the RNA polymerase $\alpha$ subunit, which was taken as the loading control.

\section{MsRbpA interacts with the $\beta$ subunit of RNA polymerase}

The chemical cross-linker HSAB had been previously used to locate the binding site of the $\omega$ subunit to the $\beta^{\prime}$ subunit on RNA polymerase (Gentry \& Burgess, 1993). We used the same strategy to locate the binding of MsRbpA on $M$. smegmatis core RNA polymerase purified from $30 \mathrm{~h}$ cultures of M. smegmatis SM07. The hetero-bifunctional cross-linker sulfo-HSAB is modified by the attachment of a sulfo group compared to the free HSAB used by Gentry \& Burgess (1993), rendering it water soluble. Cross-linking of MsRbpA to RNA polymerase involved two steps: derivatizing $\left[{ }^{35}\right.$ S]MsRbpA (Supplementary Fig. S5a) with sulfo-HSAB, followed by incubating the derivatized MsRbpA with core RNA polymerase and exposing the mixture to UV light (Supplementary Fig. S5b). The first step, derivatization of $\left[{ }^{35} \mathrm{~S}\right] \mathrm{MsRbpA}$, added an azidobenzoate $(\mathrm{AB})$ group to free amino groups on MsRbpA to make MsRbpA-AB. MsRbpA was made, in this case, from cells labelled with $\left[{ }^{35} \mathrm{~S}\right]$ methionine in order to create a tag distinct from the spectrophotometric identity. The product of the crosslinking, $N$-hydroxysuccinimide (NHS), absorbs at $260 \mathrm{~nm}$. Seven residues can be modified in this way (MsRbpA has six lysines and the amino-terminus). This step was monitored 
(a)

\begin{tabular}{|c|c|c|c|c|c|c|c|c|c|c|c|c|c|c|}
\hline Core $(100 \mathrm{nM})$ & $+\quad+$ & + & + & + & + & + & + & + & + & + & + & + & + & + \\
\hline SigA (200 nM) & $+\quad+$ & + & + & + & + & + & + & + & + & + & + & + & + & + \\
\hline DMSO (5\%) & + & + & + & + & + & + & + & + & + & + & + & + & + & + \\
\hline $\operatorname{Rif}(\mu \mathrm{M})$ & 0 & 5 & 10 & 20 & 40 & 80 & 100 & 1 & 5 & 10 & 20 & 40 & 80 & 100 \\
\hline MsRbpA (200 nM) & + & + & + & + & + & + & + & - & - & - & - & - & - & - \\
\hline
\end{tabular}

(b)

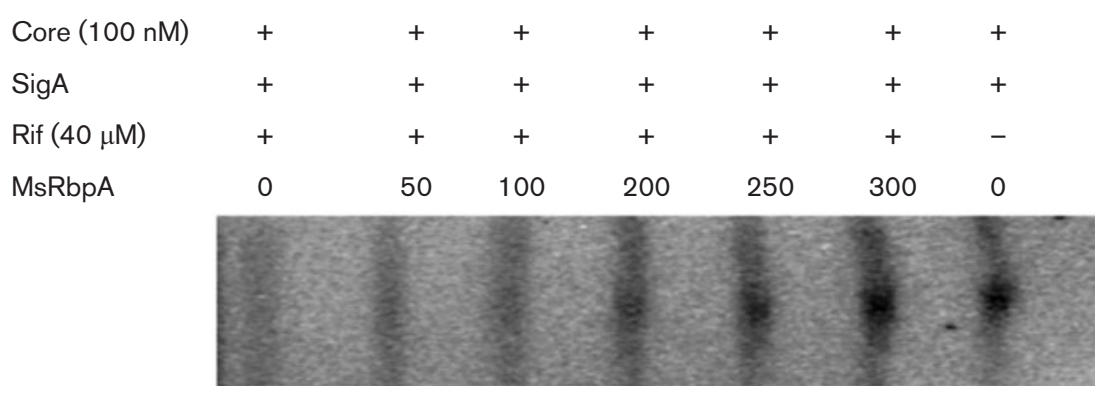

Fig. 4. MsRbpA rescues RNA polymerase activity in the presence of rifampicin. (a) Single-round promoter-specific gel-based transcription assay in the presence of different concentrations of rifampicin at constant concentration of MsRbpA (200 nM). The assays were carried out on the $M$. tuberculosis rel promoter fragment amplified from pVJP16 using primers PRelF and PRelR. Rifampicin was dissolved in DMSO. (b) Single-round promoter-specific transcription assay in the presence of different concentrations of MsRbpA and a fixed concentration of rifampi$\operatorname{cin}(40 \mu \mathrm{M})$. by observing the increase in $A_{260}$ due to release of NHS ester (Supplementary Fig. S5c). $\left[{ }^{35} \mathrm{~S}\right] \mathrm{MsRbpA}$ eluted in the void volume of a Sephadex G25 column, and the released product of cross-linking, NHS, eluted in the included volume. The last step involved the actual cross-linking of MsRbpA to RNA polymerase. When the phenyl azide groups (attached to $\left.\left[{ }^{35} \mathrm{~S}\right] \mathrm{MsRbpA}-\mathrm{AB}\right)$ were exposed to UV light $(254 \mathrm{~nm})$ there was formation of highly reactive phenylnitrene, which created covalent linkages with a variety of molecules. Such cross-linked products to RNA polymerase subunits were detected due to the formation of a covalent adduct on SDS gel which was identified by both anti-MsRbpA and antiRNA polymerase subunit antibodies. The observed product was expected to have a size approximating the molecular mass of MsRbpA plus that of the specific subunit. The crosslinking reactions were carried out in the dark, according to the manufacturer's instructions. The products of crosslinking were probed with anti-MsRbpA, anti-M. tuberculosis $\beta$, anti-M. tuberculosis $\beta^{\prime}$, anti-M. smegmatis $\alpha$ and anti- $M$. smegmatis $\omega$ antibodies. We observed a shift in the molecular mass of the $\beta$ subunit after the photo-crosslinking reaction, in agreement with the shift in the molecular mass of the MsRbpA band (lanes 5 and 6 in Fig. 6a; lane 2 in Fig. 6b). The Western analysis with anti-M. tuberculosis $\beta^{\prime}$, anti-M. smegmatis $\alpha$ and anti-M. smegmatis $\omega$ antibodies did not show any shift in band position (Fig. 6c, d).

\section{MsRbpA does not restore the activity of Rif ${ }^{\mathrm{R}}$ RNA polymerases in the presence of rifampicin at the IC $_{50}$}

As both rifampicin and MsRbpA bind to the $\beta$ subunit of RNA polymerase, we determined the effect of MsRbpA on an RNA polymerase purified from a rifampicin-resistant $\left(\mathrm{Rif}^{\mathrm{R}}\right)$ strain of $M$. smegmatis. We generated Rif ${ }^{\mathrm{R}}$ mutants of M. smegmatis SM07 by serial culturing of the strain from lower $\left(5 \mu \mathrm{g} \mathrm{ml}^{-1}\right)$ to higher $\left(50 \mu \mathrm{g} \mathrm{ml}^{-1}\right)$ concentrations of rifampicin (Supplementary Fig. S6a). After scoring the Rif $^{\mathrm{R}}$ strains for resistance to $100,200,300$ and $400 \mu \mathrm{g}$ rifampicin $\mathrm{ml}^{-1}$ (Supplementary Fig. S6b), we checked whether the strains undergo reversion in the absence of antibiotic (Supplementary Fig. S6c, d). The selected strains were named as SM0747 (MIC of rifampicin 200-300 $\mu \mathrm{g}$ $\mathrm{ml}^{-1}$ ), SM0734 (MIC of rifampicin $\sim 300-400 \mu \mathrm{g} \mathrm{ml}{ }^{-1}$ ) and SM0748 (MIC of rifampicin $>400 \mu \mathrm{g} \mathrm{ml}^{-1}$ ). The Rif ${ }^{\mathrm{R}}$ strains were also grown in $\mathrm{MB} 7 \mathrm{H} 9$ broth and their growth curves were recorded at different concentrations of rifampicin (Supplementary Fig. S6e). They were characterized for the $r p o B$ mutations by sequencing amplicons obtained using primers R3CF and R3CR (Table 2) on genomic DNA of $M$. smegmatis strains SM07, SM0747, SM0734 and SM0748. DNA sequencing was carried out by cycle sequencing using the BigDye Terminator Cycle Sequencing kit v3.0 (Applied Biosystems) and was analysed on an ABI3100 Genetic Analyser (Applied Biosystems). To detect the sequence variants in the Rif ${ }^{\mathrm{R}}$ clusters of the $r p o B$ gene, we compared the SM07 sequence with those of SM0747, SM0734 and SM0748 using CLUSTAL w 2 (http:// www.ebi.ac.uk/Tools/clustalw2/index.html). The mutations were scored as D432Y (in the case of SM0747) and S447L (in the case of SM0734 and SM0748) (Supplementary Fig. S6f). The results of the Rif ${ }^{\mathrm{R}}$ mutations are in agreement with those obtained by Jin \& Gross (1988) in E. coli. The $\mathrm{IC}_{50}$ (concentration equivalent to the minimum concentration required for $50 \%$ inhibition of multiple-round transcription activity) of rifampicin for the 
(a)

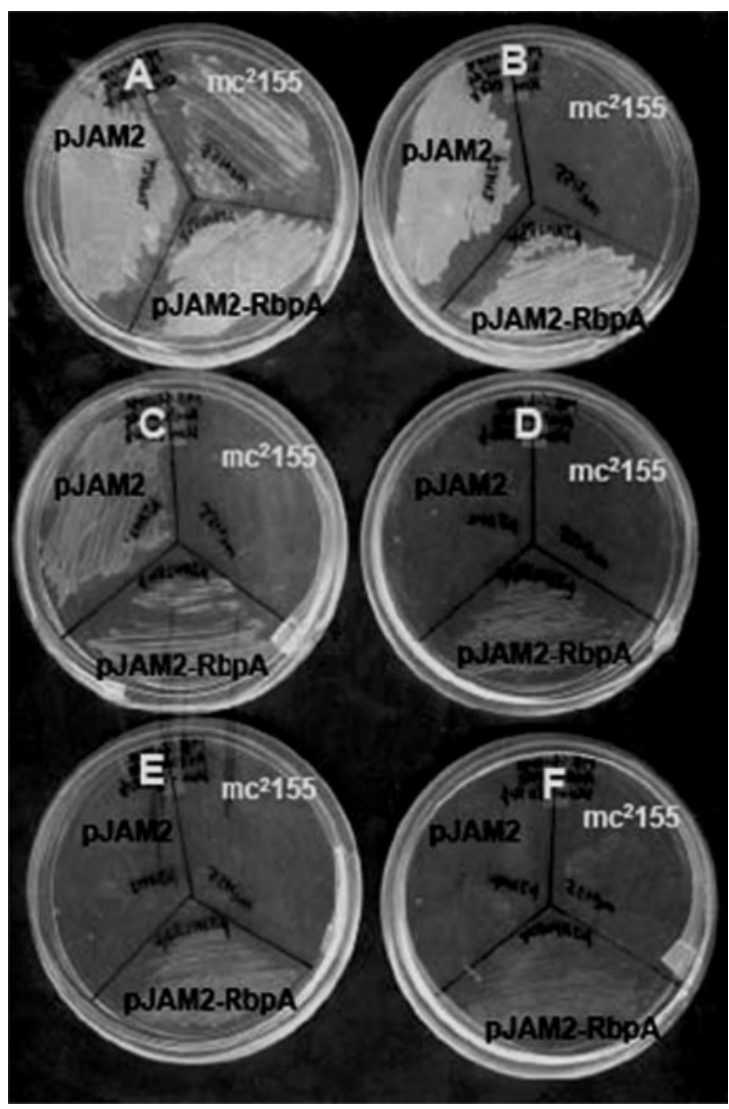

(b)
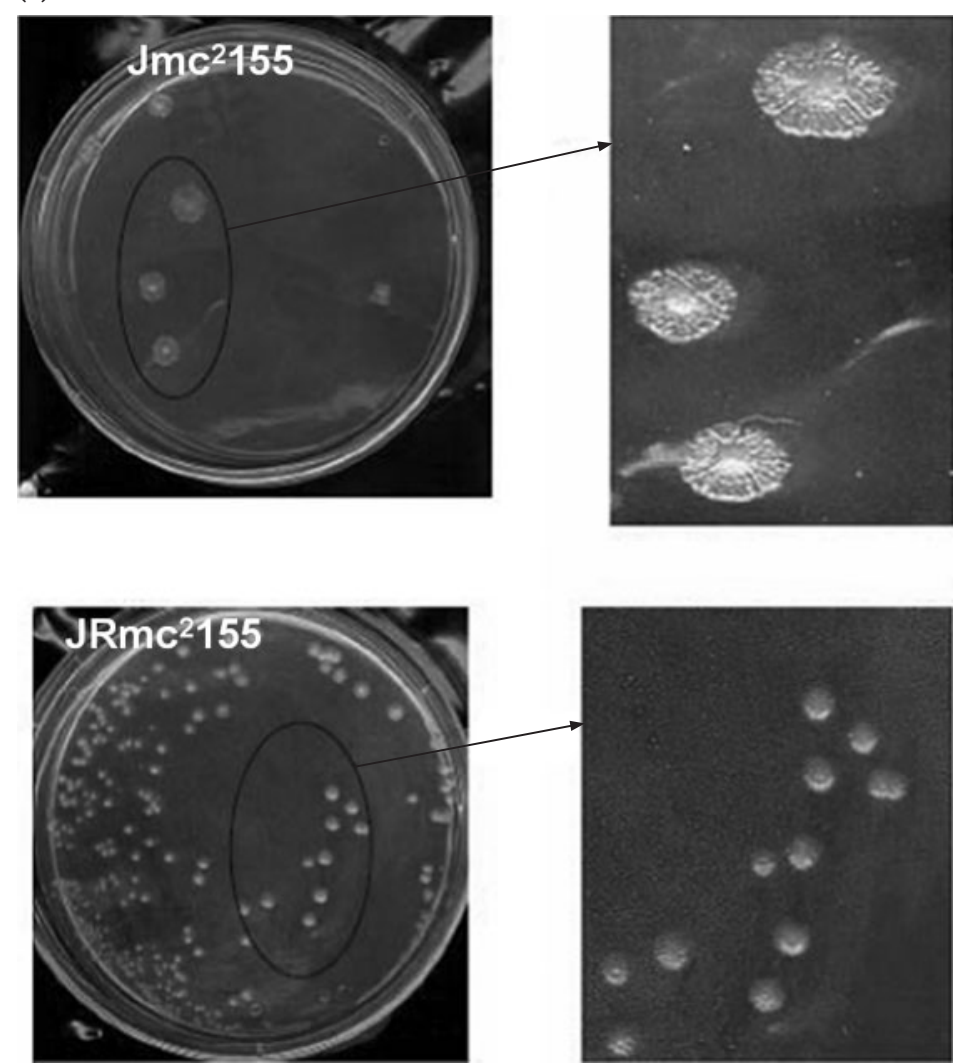

(c)

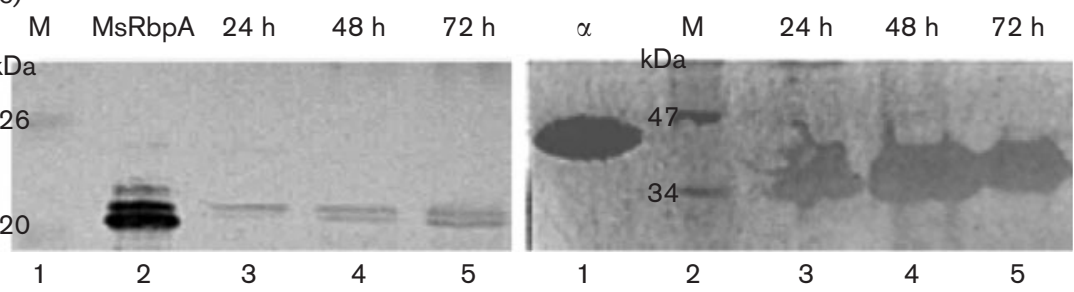

Fig. 5. In vivo studies on MsRbpA in M. smegmatis. (a) Overexpression of MsRbpA increases the rifampicin tolerance in $M$. smegmatis. Strains $\mathrm{mc}^{2} 155, \mathrm{Jmc}^{2} 155$ (pJAM2) and JRmc ${ }^{2} 155$ (pJAM2MsRbpA) were plated on MB7H9 agar supplemented with $2 \%(w / v)$ glucose (plates A to F), $2 \%(w / v)$ acetamide (plates $A$ to $F$ ) and $25 \mu \mathrm{g}$ kanamycin $\mathrm{ml}^{-1}$ (plates B to F), along with different concentrations of rifampicin: plate $A, 0 \mu \mathrm{g} \mathrm{ml}^{-1}$; plate $B, 0 \mu \mathrm{g} \mathrm{ml}^{-1}$; plate $\mathrm{C}, 10 \mu \mathrm{g} \mathrm{ml}^{-1}$; plate $\mathrm{D}, 20 \mu \mathrm{g} \mathrm{ml}{ }^{-1}$; plate $\mathrm{E}$, $40 \mu \mathrm{g} \mathrm{ml}^{-1}$; plate $\mathrm{F}, 80 \mu \mathrm{g} \mathrm{ml}^{-1}$. Strain $\mathrm{JRmc}^{2} 155$ (pJAM2MsRbpA) showed growth up to $80 \mu \mathrm{g}$ rifampicin $\mathrm{ml}^{-1}$, while $\mathrm{Jmc}^{2} 155$ (pJAM2) did not grow at 20,40 or $80 \mu \mathrm{g}$ rifampicin $\mathrm{ml}^{-1}$. (b) Change in colony morphology upon overexpressing MsRbpA in M. smegmatis. Colonies of strain $\mathrm{mc}^{2} 155$ transformed with pJAM2 (strain $\mathrm{Jmc}^{2} 155$ ) and pJAM2MsRbpA (strain $\mathrm{JRmc}^{2}{ }^{155}$ ) are shown. The strains were grown for 7 days on MB7H9 agar supplemented with $2 \%(\mathrm{w} / \mathrm{v}) \mathrm{glucose}, 2 \%$ (w/v) acetamide and $25 \mu \mathrm{g}$ kanamycin $\mathrm{ml}^{-1}$. (c) Growth-dependent Western analysis using anti-MsRbpA antibody on the cell-free lysates from $24 \mathrm{~h}, 48 \mathrm{~h}$ and $72 \mathrm{~h} \mathrm{M}$. smegmatis cultures (left panel); samples containing $100 \mu \mathrm{g}$ protein were loaded in each lane. The control blot was probed using anti-M. smegmatis $\alpha$ antibody (right panel). The expression level of MsRbpA rises in stationary phase but the amount appears to be very low as compared to RNA polymerase, whose comparative expression was greater throughout the growth cycle as judged by the Western analysis. Left panel: lane 1, prestained molecular mass markers showing $20 \mathrm{kDa}$ and $26 \mathrm{kDa}$ bands; lane 2, control protein MsRbpA; lane 3, $24 \mathrm{~h}$ culture load; lane 4, 48 h culture load; lane 5, $72 \mathrm{~h}$ culture load. Right panel: lane 1, control protein M. smegmatis RNA polymerase $\alpha$ subunit; lane 2, prestained molecular mass markers showing $34 \mathrm{kDa}$ and $47 \mathrm{kDa}$ bands; lane 3, $24 \mathrm{~h}$ culture load; lane 4, $48 \mathrm{~h}$ culture load; lane 5, 72 h culture load. 
(a)

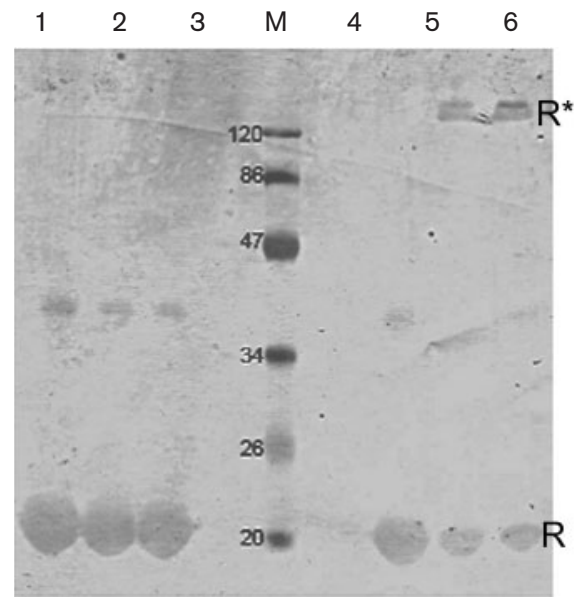

(b)

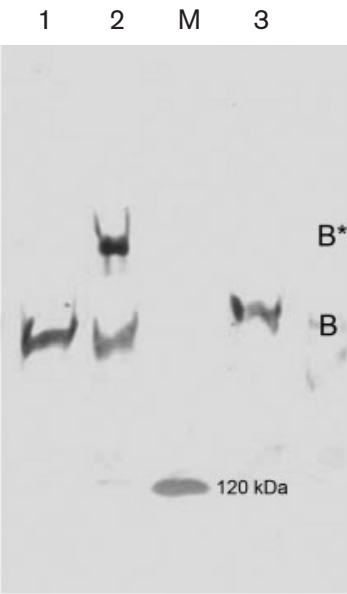

(c)

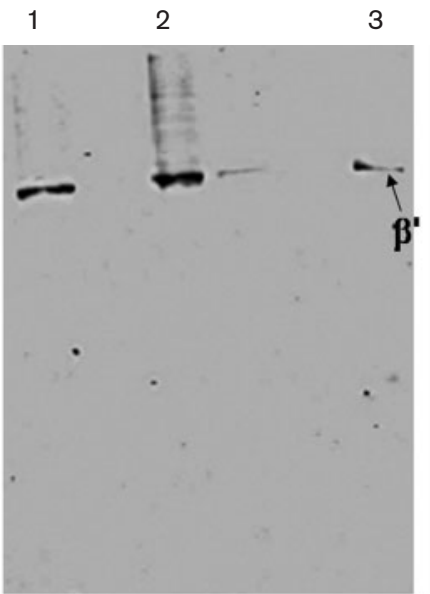

(d)

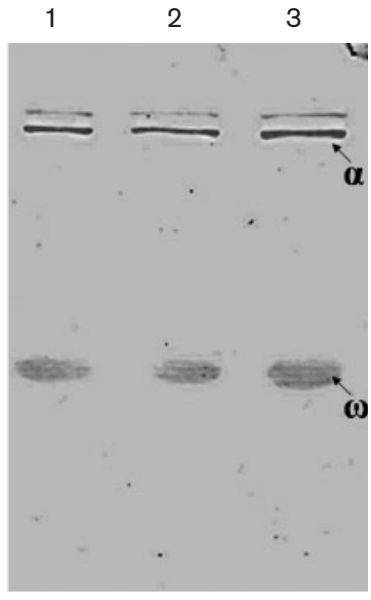

Fig. 6. Cross-linking of MsRbpA with RNA polymerase. (a) Western blot analysis of MsRbpA-RNA polymerase cross-linked products separated by $12 \%$ SDS-PAGE and probed using anti-MsRbpA antibody. The lanes represent the following reaction conditions: lane 1, MsRbpA; lane 2, MsRbpA+sulfo-HSAB; lane 3, MsRbpA+sulfo-HSAB+RNA polymerase; lane M, Prestained Marker SMO441 (Fermentas; sizes in kDa indicated); lane 4, MsRbpA + sulfo-HSAB + UV light (254 nm for $8 \mathrm{~min}$ ); lane 5, MsRbpA+sulfo-HSAB+RNA polymerase+UV light (254 nm for $6 \mathrm{~min}$ ); lane 6, MsRbpA+sulfo-HSAB+RNA polymerase +UV light (254 $\mathrm{nm}$ for $8 \mathrm{~min}$ ) ( $R^{\star}$, cross-linked adduct of MsRbpA-RNA polymerase; R, free MsRbpA). (b) Western blot analysis of MsRbpA-RNA polymerase cross-linked products separated by $6 \%$ SDS-PAGE and probed using anti$M$. tuberculosis $\beta$ antibody. The lanes represent the following reaction conditions: lane 1, RNA polymerase + MsRbpA+sulfoHSAB (no UV); lane 2, RNA polymerase+MsRbpA + sulfo-HSAB + UV light (254 nm for $8 \mathrm{~min}$ ); M, molecular mass marker, $120 \mathrm{kDa}$; lane 3, reference $M$. tuberculosis $\beta$ ( $\mathrm{B}^{\star}, \beta-\mathrm{MsRbpA}$ cross-linked adduct; $\mathrm{B}$, free $\beta$ subunit). (c) Western blot analysis of MsRbpA-RNA polymerase cross-linked products separated by $6 \%$ SDS-PAGE and probed using anti-M. tuberculosis $\beta^{\prime}$ antibody. The lanes represent the following reaction conditions: lane 1, RNA polymerase + MsRbpA + sulfo-HSAB (no UV); lane 2, RNA polymerase + MsRbpA + sulfo-HSAB + UV light (254 nm for $8 \mathrm{~min}$ ); lane 3, reference M. tuberculosis $\beta^{\prime}$. (d) Western blot analysis of MsRbpA-RNA polymerase cross-linked products separated by $6 \%$ SDS-PAGE and probed using anti-M. smegmatis $\alpha$ and anti-M. smegmatis $\omega$ antibodies. The lanes represent the following reaction conditions: lane 1, RNA polymerase +MsRbpA + sulfo-HSAB (no UV); lane 2, RNA polymerase+MsRbpA+sulfo-HSAB + UV light (254 nm for $8 \mathrm{~min}$ ); lane 3, reference M. smegmatis RNA polymerase.

rifampicin-sensitive RNA polymerase from SM07 was $0.05 \mu \mathrm{g} \mathrm{ml}{ }^{-1}$. The RNA polymerases purified from these strains (Supplementary Fig. S6g) had $\mathrm{IC}_{50}$ values of $4.4 \mathrm{mg}$ $\mathrm{ml}^{-1}$ (SM0747), $6.4 \mathrm{mg} \mathrm{ml}^{-1}$ (SM0734) and $6.2 \mathrm{mg} \mathrm{ml}^{-1}$ (SM0748) (Supplementary Table S2). The rifampicinsensitive RNA polymerase from $\mathrm{SM} 07$ had an $\mathrm{IC}_{50}$ value of $0.05 \mu \mathrm{g} \mathrm{ml}^{-1}$.

We tested for the rescue of rifampicin inhibition by MsRbpA of $\mathrm{Rif}^{\mathrm{R}}$ RNA polymerases as against $\mathrm{Rif}^{\mathrm{S}}$ RNA polymerase. In these cases, promoter-specific multipleround transcription assays were carried out for the $\mathrm{Rif}^{\mathrm{S}}$ and $\mathrm{Rif}^{\mathrm{R}}$ RNA polymerases at their respective $\mathrm{IC}_{50}$ levels of rifampicin. Although the activity of $\mathrm{Rif}^{\S} \mathrm{RNA}$ polymerase was rescued by MsRbpA at the $\mathrm{IC}_{50}$ value of $0.05 \mu \mathrm{g} \mathrm{ml}^{-1}$, there was no recovery of transcription activity of Rif ${ }^{\mathrm{R}} \mathrm{RNA}$ polymerases from SM0747, SM0734 and SM0748, at their respective $\mathrm{IC}_{50}$ values of $4.4,6.4$ and $6.2 \mathrm{mg}$ rifampicin $\mathrm{ml}^{-1}$, even when assayed at 8:1 molar ratio of MsRbpA to RNA polymerase (Supplementary Fig. S6h).

\section{DISCUSSION}

The work on RbpA in S. coelicolor by Newell et al. (2006) laid the foundation for the novel mechanism of protection of RNA polymerase from the classical inhibitor rifampicin. Whether protein-protein interactions within the transcription machinery ultimately lead to the rifampicin tolerance is an important consideration. We have already mentioned that differential sensitivity to rifampicin of core RNA polymerase $-\sigma^{70}$ or $-\sigma^{32}$ complex (Węgrzyn et al., 1998) may arise from altered conformation of the transcription machinery, although it was not demonstrated clearly. Previous proteomic analyses by us indicated that in stationary phase, rifampicin binding to the enzyme is blocked by several proteins (Mukherjee \& Chatterji, 2008). Similarly, activation of $\sigma^{\mathrm{B}}$-dependent transcription in Bacillus subtilis by sublethal doses of rifampicin may arise due to the other proteins interacting with RNA polymerase (Bandow et al., 2002). Proof of the transcriptional machinery of M. tuberculosis surviving the lethal rifampicin 
treatment was obtained when mRNA transcripts were detected after treatment of this organism with rifampicin (Hu et al., 2000), further raising the question of whether the stress-induced changes in the proteome lead to insulation of mycobacterial RNA polymerase against rifampicin.

In this study we have attempted to dissect the role of MsRbpA with respect to its ability to confer rifampicin tolerance to RNA polymerase in mycobacteria. Our findings are summarized below.

(a) The interaction between MsRbpA and reconstituted RNA polymerase mitigates the inhibition of transcription even at $100 \mu \mathrm{M}$ rifampicin, in an M. tuberculosis rel promoter-specific single-round transcription assay.

(b) MsRbpA increases the $\mathrm{IC}_{50}$ of rifampicin for purified RNA polymerase from $M$. smegmatis SM07 in a multipleround transcription assay on the M. tuberculosis rel promoter and $M$. tuberculosis rrn promoter (Supplementary Table S3), indicating that perhaps the effect of MsRbpA is not promoter specific.

(c) MsRbpA acts by binding to the $\beta$ subunit of RNA polymerase. As the $\beta$ subunit is the site of action of rifampicin, we checked the action of MsRbpA on $\operatorname{Rif}^{\mathrm{R}} \mathrm{RNA}$ polymerase. For that purpose we developed Rif ${ }^{\mathrm{R}}$ mutants of M. smegmatis SM07 and mapped the mutation sites on the $\mathrm{Rif}^{\mathrm{R}}$ clusters of the $\beta$ subunit. However, we observed no change in the $\mathrm{IC}_{50}$ values in these cases, even with an $8: 1$ molar ratio of MsRbpA: RNA polymerase.

At this point, we do not know where exactly MsRbpA binds the $\beta$ subunit. However, our results indicate that the binding site may overlap with the rifampicin-binding domain. Such a proposition seems reasonable, as we know that there are four such domains along the length of the $\beta$ subunit (Jin \& Gross, 1988). The mode of action of MsRbpA in relieving RNA polymerase from rifampicin inhibition could be by shielding the polymerase against rifampicin or causing a conformational change in the binding site of rifampicin so that the interaction between RNA polymerase and rifampicin cannot take place. It should be mentioned here that we were unable to detect any interaction between MsRbpA and rifampicin in vitro (data not shown).

It was also intriguing why MsRbpA did not have a similar rifampicin rescue effect on a iff $^{\mathrm{R}} \mathrm{RNA}$ polymerase as it had on a Rif $^{S}$ RNA polymerase. Such behaviour makes it tempting to speculate upon a kind of switching in the behaviour of the cell in response to rifampicin when RNA polymerase evolves from a $\mathrm{Rif}^{\mathrm{S}}$ to a $\mathrm{Rif}^{\mathrm{R}}$ form, in which case the role of MsRbpA in providing phenotypic tolerance to rifampicin becomes redundant. Thus, it appears that MsRbpA plays a role in protecting the Rif $^{S}$ RNA polymerase when the cell attempts to evolve into a genetically $\mathrm{Rif}^{\mathrm{R}}$ strain.

(d) The in vivo data regarding the M. tuberculosis homologue of MsRbpA, Rv2050, have been discussed previously. The overexpression of Rv2050 in an rbpA null mutant of $S$. coelicolor increased the resistance level from 0.75 to $2 \mu \mathrm{g}$ rifampicin $\mathrm{ml}^{-1}$. On similar lines, when we overexpressed MsRbpA in wild-type M. smegmatis, we found that the MIC values for rifampicin rose from $20 \mu \mathrm{g}$ $\mathrm{ml}^{-1}$ to $85 \mu \mathrm{g} \mathrm{ml}^{-1}$. Thus, our in vivo data corroborated the in vitro data on MsRbpA obtained from the transcription assays.

(e) Microarray data of Murphy \& Brown (2007) revealed that Rv2050 was upregulated under conditions of aerated starvation, starvation under $50 \%$ dissolved oxygen, and in vitro hypoxia (Wayne model; Wayne \& Hayes, 1996), as well as in mouse macrophages. Rv2050 was also upregulated under conditions of heat shock, diamide stress and dormant stage (AstraZeneca R\&D, Bangalore, personal communication). Thus, it appears that Rv2050 is induced by multiple stress conditions. MsRbpA (MSMEG_3858) (which is $100 \%$ similar to Rv2050) was also found to be upregulated in stationary-phase cultures of M. smegmatis. It will be interesting to find out whether MsRbpA has any effect on cells other than those described.

\section{ACKNOWLEDGEMENTS}

A. D. thanks the Council of Scientific and Industrial Research (CSIR), New Delhi, and A.K.V. acknowledges the Department of Biotechnology (DBT), Government of India, New Delhi, for their respective research fellowships. We thank Professor V. Nagaraja (Indian Institute of Science, Bangalore) for providing us with anti- $M$. tuberculosis $\beta^{\prime}$ and anti- $M$. tuberculosis $\beta$ antibodies. The contribution of AstraZeneca R\&D, Bangalore, in providing us with microarray data and plasmids is sincerely acknowledged. The authors would also like to thank Professor Anuranjan Anand from Jawaharlal Nehru Centre for Advanced Scientific Research (JNCASR), Bangalore, for allowing access to the DNA sequencing facility in his laboratory. We acknowledge the help of Mr Ramesh Reddy (JNCASR) in assisting us with the DNA sequencing.

\section{REFERENCES}

Artsimovitch, I., Vassylyeva, M. N., Svetlov, D., Svetlov, V., Perederina, A., Igarashi, N., Matsugaki, N., Wakatsuki, S., Tahirov, T. H. \& Vassylyev, D. G. (2005). Allosteric modulation of the RNA polymerase catalytic reaction is an essential component of transcriptional control by rifamycins. Cell 122, 351-363.

Bandow, J. E., Brotz, H. \& Hecker, M. (2002). Bacillus subtilis tolerance of moderate concentrations of rifampin involves the $\sigma^{\mathrm{B}}$ dependent general and multiple stress response. J Bacteriol 184, 459467.

Chowdhury, R. P., Gupta, S. \& Chatterji, D. (2007). Identification and characterization of the dps promoter of Mycobacterium smegmatis: promoter recognition by stress-specific extracytoplasmic function sigma factors $\sigma^{\mathrm{H}}$ and $\sigma^{\mathrm{F}}$. J Bacteriol 189, 8973-8981.

Flåtten, I., Morigen \& Skartstad, K. (2009). DnaA protein interacts with RNA polymerase and partially protects it from the effect of rifampicin. Mol Microbiol 71, 1018-1030.

Gentry, D. R. \& Burgess, R. R. (1993). Cross-linking of Escherichia coli RNA polymerase subunits: identification of $\beta^{\prime}$ as the binding site for $\omega$. Biochemistry 32, 11224-11227. 
Hu, Y., Mangan, J., Dhillon, J., Sole, K., Mitchison, D., Butcher, P. \& Coates, A. (2000). Detection of m-RNA transcripts and active transcription in persistent Mycobacterium tuberculosis induced by exposure to rifampin and pyrazinamide. J Bacteriol 182, 6358-6365.

Jain, V., Sujatha, S., Ojha, A. K. \& Chatterji, D. (2005). Identification and characterization of rel promoter element of Mycobacterium tuberculosis. Gene 351, 149-157.

Jin, D. J. \& Gross, C. A. (1988). Mapping and sequencing of mutations in the Escherichia coli rpoB gene that lead to rifampicin resistance. J Mol Biol 202, 45-58.

Kumar, M. \& Chatterji, D. (2008). Cyclic di-GMP: a second messenger required for long-term survival, but not for biofilm formation, in Mycobacterium smegmatis. Microbiology 154, 2942-2955.

Mackay, J. P., Sunde, M., Lowry, J. A., Crossley, M. \& Matthews, J. M. (2007). Protein interactions: is seeing believing? Trends Biochem Sci 32, 530-531.

Mathew, R., Ramakanth, M. \& Chatterji, D. (2005). Deletion of the gene rpoZ, encoding the $\omega$ subunit of RNA polymerase, in Mycobacterium smegmatis results in fragmentation of the $\beta^{\prime}$ subunit in the enzyme assembly. J Bacteriol 187, 6565-6570.

Miller, L. P., Crawford, J. T. \& Shinnick, T. M. (1994). The $r p o B$ gene of Mycobacterium tuberculosis. Antimicrob Agents Chemother 38, 805-811.

Mukherjee, R. \& Chatterji, D. (2008). Stationary phase induced alterations in mycobacterial RNA polymerase assembly: a cue to its phenotypic resistance towards rifampicin. Biochem Biophys Res Commun 369, 899-904.

Murphy, D. J. \& Brown, J. R. (2007). Identification of gene targets against dormant phase Mycobacterium tuberculosis infections. BMC Infect Dis 7, 84 .
Newell, K. V., Thomas, D. P., Brekasis, D. \& Paget, M. S. B. (2006). The RNA polymerase-binding protein RbpA confers basal levels of rifampicin resistance on Streptomyces coelicolor. Mol Microbiol 60, 687-696.

Nguyen, L. \& Thompson, C. J. (2006). Foundations of antibiotic resistance in bacterial physiology: the mycobacterial paradigm. Trends Microbiol 14, 304-312.

Paget, M. S., Molle, V., Cohen, G., Aharonowitz, Y. \& Buttner, M. J. (2001). Defining the disulfide stress response in Streptomyces coelicolor A3(2): identification of the $\sigma^{\mathrm{R}}$ regulon. Mol Microbiol 42, 1007-1020.

Sassetti, C. M., Boyd, D. H. \& Rubin, E. J. (2003). Genes required for mycobacterial growth defined by high density mutagenesis. Mol Microbiol 48, 77-84.

Triccas, J. A., Parish, T., Britton, W. J. \& Gicquel, B. (1998). An inducible expression system permitting efficient purification of recombinant antigen from Mycobacterium smegmatis. FEMS Microbiol Lett 167, 151-156.

Villain-Guillot, P., Bastide, L., Gualtieri, M. \& Leonetti, J. P. (2007). Progress in targeting bacterial transcription. Drug Discov Today 12, 200-208.

Wayne, L. G. \& Hayes, L. G. (1996). An in vitro model for sequential study of shiftdown of Mycobacterium tuberculosis through two stages of nonreplicating persistence. Infect Immun 64, 2062-2069.

Węgrzyn, A., Szalewska-Palasz, A., Blaszczak, A., Libereck, K. \& Węgrzyn, G. (1998). Differential inhibition of transcription from $\sigma^{70}$ and $\sigma^{32}$-dependent promoters by rifampicin. FEBS Lett 440, 172-174.

Edited by: G. R. Stewart 